Al-Bayyinah: Journal of Islamic Law- ISSN: 1979-7486 (p); 2580-5088 (e) Volume VII Number 1, pp. 41- 56

\title{
PANDANGAN HUKUM ISLAM TENTANG STATUS ANAK PEREMPUAN YANG LAHIR KURANG DARI 6 BULAN SETELAH AKAD NIKAH
}

\section{Hj. Hamsidar}

(Dosen Tetap Hukum Keluarga Islam IAIN Bone)

\section{Abstract}

The view of Islamic law on the establishment of the law and the guardian of his marriage for a girl born less than 6 months from a pregnant marriage differs between classical fiqh scholars with applicable laws in Indonesia (Law Number 1 of 1974 and KHI). According to the scholars of girls born less than 6 months old, they are illegitimate children and the determination of the marriage and guardian of their marriage cannot be with their biological father. Whereas according to applicable law in Indonesia (Law Number 1 Year 1974 and KHI) a girl born less than 6 months from a pregnant marriage is still a legitimate child and her marriage certificate and guardianship is fixed on her biological father. Because of differences of opinion between the ulama and the applicable law in Indonesia regarding this matter, there are two references which all have a strong foundation or foundation, and depending on which guidelines we want to follow.

Kata Kunci: Wali nikah, perkawinan hamil, nasab, hukum Islam 


\section{A. Latar Belakang}

Perwalian dalam hukum perkawinan Islam adalah salah satu unsur pembeda dengan hukum perkawinan dalam syariat agama yang lainnya. Oleh karena itu ketentuan yang berhubungan dengan perwalian dalam hukum perkawinan Islam, harus tunduk terhadap hukum Islam itu sendiri yang menentukan sah atau tidak sahnya seorang bertindak sebagai wali dalam perkawinan. Jumhur ulama, seperti Malik, atsTsauri, Laits, dan Syafi'i, berpendapat bahwa wali dalam pernikahan adalah ahli waris, tetapi bukan paman dari ibu, bibi dari ibu, saudara seibu, dan keluarga dzawil arham. Syafi'i berkata, nikah seorang wanita tidak dapat dilakukan kecuali dengan pernyataan wali qarib 'dekat', jika ia tidak ada boleh diwakilkan oleh wali jauh. Jika ia tidak ada juga hakim sebagai walinya.

Pada hukum Islam, melakukan perkawinan secara sah, harus dilakukan sesuai dengan rukun dan syarat dalam perkawinan. Perkawinan tersebut akan batal apabila syarat maupun rukun yang dimaksud tidak terpenuhi. Hukum Islam memasukkan adanya wali bagi mempelai wanita sebagai salah satu rukun perkawinan. Suatu perkawinan yang dilangsungkan tanpa adanya seorang wali atau wali bukanlah orang yang berhak, maka perkawinan tersebut menjadi batal.

Perwalian dalam perkawinan menurut hukum Islam pada dasarnya terbagi atas wali nasab dan wali hakim. Wewenang wali dapat berpindah ke tangan hakim apabila terdapat hal-hal berikut ini seperti, ada pertentangan diantara wali-wali, bilamana walinya tak ada dalam artian tidak ada yang absolut (mati, hilang) atau karena tidak hadir (tidak diketahui keberadaannya). ${ }^{2}$

Melihat realitas yang terjadi saat ini serta pergaulan muda mudi masa kini banyak ditemukan terjadinya kasus-kasus perzinahan yang berujung hamilnya si perempuan. Melahirlah anak perempuan yang kurang dari 6 bulan setelah akad nikah yang akhirnya statusnya tidak jelas, sehingga wali nikah si anak

${ }^{1}$ Sayyid Sabiq, Fiqih Sunnah, Terjemahan. Nor Hasanuddin, Dkk, Jilid III (Cet. I ; Jakarta: Pena Pundi Aksara, 2006), h. 18-19.

${ }^{2}$ Sayyid Sabiq, Fiqih Sunnah, Terjemahan. Nor Hasanuddin., h. 24. 
dikemudian hari pun juga tidak jelas. Dengan demikian persoalan perwalian nasabiyah dalam perkawinan berkaitan langsung dengan sah atau tidak sahnya status sebagai anak menurut hukum.

Pada dasarnya, upaya menghubungkan anak zina menjadi anak sah dengan tujuan perlindungan hak anak memang terkesan mulia. Akan tetapi usaha tersebut juga menimbulkan permasalahan yang cukup rumit, karena berhubungan dengan masalah hukum. Berbagai permasalahan ini memerlukan suatu solusi dan jawaban yang memerlukan penelitian yang lebih mendalam.

\section{B. Rumusan Masalah}

Adapun rumusan masalah pada penelitian ini adalah:

1. Bagaimana hubungan nasab terhadap ayahnya bagi anak perempuan yang lahir kurang dari 6 bulan dari perkawinan hamil perspektif hukum Islam?

2. Bagaimana penetapan wali nikahnya bagi anak perempuan yang lahir kurang dari 6 bulan dari perkawinan hamil perspektif hukum Islam?

\section{Tujuan dan Kegunaan Penelitian}

Adapun tujuan yang akan dicapai dalam penelitian ini sebagai berikut:

1. Untuk mengetahui nasab terhadap ayahnya bagi perempuan yang lahir kurang dari 6 bulan setelah akad nikah dari perkawinan hamil perspektif hukum Islam.

2. Untuk mengetahui penetapan wali nikahnya bagi perempuan yang lahir kurang dari 6 bulan setelah akad nikah dari perkawinan hamil perspektif hukum Islam.

Sedangkan kegunaan yang sangat diharapkan sebagai berikut:

1. Dapat berguna sebagai bahan masukan yang berharga untuk masyarakat, khususnya yang beragama Islam tentang urgensi penetapan wali nikah bagi perempuan yang lahir kurang dari 6 bulan setelah akad nikah dari perkawinan hamil perspektif hukum islam.

2. Dapat dijadikan sebagai bahan kepustakaan (literature) untuk peneliti selanjutnya yang ingin meneliti lebih 
dalam terhadap masalah urgensi penetapan wali nikah bagi perempuan yang lahir kurang dari 6 bulan setelah akad nikah dari perkawinan hamil perspektif hukum Islam.

\section{Metodologi Penelitian}

Metode pengumpulan data yang digunakan pada penelitian ini adalah library research. Data atau bahan yang di peroleh adalah data sekunder yang berasal dari bahan hukum primer, bahan hukum sekunder, dan bahan hukum tertier.

Pendekatan yang digunakan adalah pendekatan syar'i dan pendekatan yuridis. Data yang dikumpulkan pada penelitian ini, kemudian diolah melalui metode kualitatif, yaitu pengolahan gagasan, ulasan, pandangan dari berbagai ahli tentang masalah yang berhubungan dengan urgensi penetapan wali nikah bagi perempuan yang lahir dari perkawinan hamil. Sedangkan, dalam melakukan analisis data, digunakan cara berpikir deduktif.

\section{E. Hasil Pembahasan}

a. Konsep Dasar Tentang Nasab dalam Hukum Islam

Eksistensi anak dalam kehidupan manusia sangat penting, maka Allah swt. mensyari'atkan adanya perkawinan. Pensyari'atan perkawinan memiliki tujuan antara lain untuk berketurunan (memiliki anak) yang baik, memelihara nasab, menghindarkan diri dari penyakit dan menciptakan keluarga yang sakinah. ${ }^{3}$

Kata nasab berasal dari kata نَسَبَّ “nasaban” yang berarti hubungan pertalian darah/keturunan. ${ }^{4}$ Sedangkan dalam kamus bahasa Indonesia, kata nasab yang diadopsi dari bahasa arab tidak mengalami pergeseran arti yang signifikan. Nasab diartikan dengan keturunan (terutama pihak Bapak) atau Pertalian keluarga. ${ }^{5}$ Sedangkan menurut

${ }^{3}$ Wahbah al- Zuhailiy, Al-Fiqh al- Islamiy wa Adillatuhu, Jilid I, Beirut: Dar al-Fikr, 1984), h. 114.

${ }^{4}$ Ahmad Warson Munawir, Kamus al-Munawir Arab-Indonesia, Ed. II, (Surabaya: Pustaka Progresif, 1997), h. 1411.

${ }^{5}$ WJS. Poerwadarminta, Kamus Besar Bahasa Indonesia. (Jakarta: Balai Pustaka, 2008), h. 38. 
Wahbah al-Zuhaili nasab didefinisikan sebagai suatu sandaran yang kokoh untuk meletakkan suatu hubungan kekeluargaan berdasarkan kesatuan darah atau pertimbangan bahwa yang satu adalah bagian dari yang lain. Jadi, orang-orang yang serumpun nasab adalah orangorang yang satu pertalian darah. ${ }^{6}$

Dengan demikian, nasab dipahami sebagai hubungan darah yang terjadi antara satu orang dengan yang lain baik jauh maupun dekat. Namun, jika membaca literatur Hukum Islam, maka kata nasab itu akan menunjuk pada hubungan keluarga yang sangat dekat, yaitu hubungan anak dengan orang tua terutama orang tua laki-laki. ${ }^{7}$

Dalam Al-Qur'an kata nasab diulang beberapa kali yaitu:

1. QS. al-Furqan (25): 54

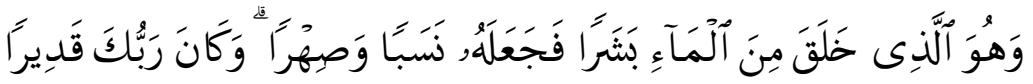

Terjemahnya: 'dan Dia (pula) yang menciptakan manusia dari air lalu Dia jadikan manusia itu (punya) keturunan dan mushaharah dan adalah Tuhanmu Maha Kuasa, ${ }^{\text {. }}$

2. QS. as-Saffat (37): 158

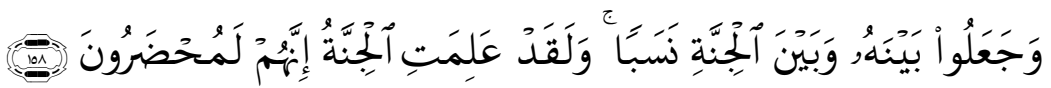

Terjemahnya: 'dan mereka adakan (hubungan) nasab antara Allah dan antara jin. dan Sesungguhnya jin mengetahui bahwa mereka benar-benar akan diseret (ke neraka)."

Kata nasab dalam ayat-ayat tersebut menunjukkan arti yang sama, yaitu adanya sebuah

${ }^{6}$ Wahbah al- Zuhailiy, Al-Fiqh al- Islamiy wa Adillatuhu, h. 7247.

7 Muhammad Jawad al-Mugniyah, al-Fiqh alaa al-Mazahib alKhamsah (Cet. VI; t.tp: t.p., 1402 H/1982 M), h. 383.

8 Muhammad Jawad al-Mugniyah, al-Fiqh alaa al-Mazahib alKhamsah, h. 364.

9 Muhammad Jawad al-Mugniyah, al-Fiqh alaa al-Mazahib alKhamsah, h. 452. 
hubungan antara satu dengan yang lain, walaupun dalam konteks yang berbeda. Dalam ensiklopedi Islam disebutkan bahwa nasab adalah pertalian kekeluargaan berdasarkan hubungan darah melalui akad perkawinan yang $\operatorname{sah}^{10}$.

Dalam Fiqih, seorang anak dapat dikatakan sah memiliki hubungan nasab dengan ayahnya jika terlahir dari perkawinan yang sah. Sebaliknya anak yang terlahir di luar perkawinan yang sah, tidak dapat disebut dengan anak yang sah. Biasa disebut dengan anak zina atau anak di luar perkawinan yang sah.

Untuk melegalisasi status anak yang sah, ada tiga syarat yang harus dipenuhi, yaitu:

1. Kehamilan bagi seorang istri bukan hal yang mustahil artinya normal dan wajar untuk hamil. Ini adalah syarat yang disetujui oleh mayoritas Ulama' kecuali Imam Hanafi.

2. Tenggang waktu kelahiran dengan pelaksanaan perkawinan sedikitnya enam bulan sejak perkawinan dilaksanakan. Menurut madzhab Maliki, batas maksimal kehamilan adalah lima Tahun. Pendapat ini didukung oleh Al-laith bin Said dan Ibad bin Al Awwam. Bahkan menurut cerita Malik, suatu ketika ada seorang wanita hamil yang datang kepadanya sambil mengatakan bahwa masa kehamilannya mencapai 7 Tahun. ${ }^{11}$

3. Suami tidak mengingkari anak tersebut melalui lembaga $1 i^{\text {'an. }}{ }^{12}$

Dalam perspektif Kompilasi Hukum Islam, pada Pasal 99 disebutkan bahwa anak sah adalah:

1. Anak yang dilahirkan dalam atau akibat perkawinan yang sah.

${ }^{10}$ Abdul Aziz Dahlan,dkk, Ensiklopedi Islam (Cet. III; jilid. IV; Jakarta: PT Ichtiar Baru Van Hoeve, 1994 ), h. 13.

${ }^{11}$ Abdul Aziz Dahlan,dkk, Ensiklopedi Islam, h. 7252.

12 Abdul Manan, Aneka Masalah Hukum Perdata Islam di Indonesia (Cet. I; Jakarta: Kencana, 2006), h. 79. 
2. Hasil pembuahan suami istri yang sah di luar rahim dan dilahirkan oleh istri tersebut. ${ }^{13}$

Dalam Pasal 100 Kompilasi Hukum Islam disebutkan: "anak yang lahir diluar perkawinan sah hanya mempunyai hubungan nasab dengan ibunya dan keluarga ibunya". Selanjutnya Pasal 101 dan 102 Kompilasi Hukum Islam menyangkut keadaan suami yang mengingkari sahnya anak dan proses yang harus ditempuhnya jika ia menyangkal anak yang dikandung atau dilahirkan oleh istrinya. Pasal 103 Kompilasi Hukum Islam berbicara mengenai asal-usul seorang anak yang hanya dibuktikan dengan akta kelahiran atau alat bukti lainnya. ${ }^{14}$

Disamping penjelasan tersebut, masalah nasab ini juga dipaparkan dalam Pasal 42 Undang-Undang Nomor 1 Tahun 1974 Tentang Perkawinan, yang berbunyi bahwa Keturunan yang sah didasarkan atas adanya perkawinan yang sah. Sebaliknya keturunan yang tidak sah adalah keturunan yang tidak didasarkan atas suatu perkawinan yang sah.

Masalah ini juga terdapat dalam Pasal 43 dan 44, sebagai berikut: Pasal 43 ayat (1) Anak yang dilahirkan di luar perkawinan hanya mempunyai hubungan perdata dengan ibunya dan keluarga ibunya, dan ayat (2) Kedudukan anak tersebut ayat (1) di atas selanjutnya akan diatur dalam peraturan pemerintah.

Didalam Pasal 44 ayat (1) Seorang suami dapat menyangkal sahnya anak yang dilahirkan oleh istrinya bilaman ia dapat membuktikan bahwa Istrinya telah berzina dan anak itu akibat daripada perzinaan tersebut. dan ayat (2) Pengadilan memberikan keputusan tentang sah/ tidaknya anak atas permintaan pihak yang bersangkutan.

Berkenaan dengan pembuktian asal usul anak, Pasal 55 Undang-Undang tentang perkawinan ditegaskan:

13 Republik Indonesia, Undang-undang Nomor 1 Tahun 1974 Tentang Perkawinan dan Kompilasi Hukum Islam (Bandung: CITRA UMBARA, t.th), h. 263.

14 Republik Indonesia, Undang-undang Nomor 1 Tahun 1974 Tentang Perkawinan dan Kompilasi Hukum Islam, h. 264. 
1. Asal-usul seoarang anak hanya dapat dibuktikan dengan akte kelahiran yang autentik, yang dikeluarkan oleh pejabat yang berwenang.

2. Bila akte kelahiran tersebut dalam ayat (1) tdak sah, pengadilan dapa

seorang anak setelah diadakan pemeriksaan yang teliti berdasarkan bukti-bukti yang memnuhi syarat.

3. Atas dasar ketentuan pengadilan tersebut ayat (2) Pasal ini, maka instansi pencatatan kelahiran yang ada dalam daerah hukum pengadilan yang mengeluarkan akte kelahiran bagi anak yang bersangkutan. ${ }^{15}$

Hal tersebut sejalan dengan Pasal 250 kitab UndangUndang Hukum perdata yang menyatakan bahwa anak sah adalah anak yang dilahirkan dan dibuat selama perkawinan. Jadi, anak yang dilahirkan dalam suatu perkawinan yang sah mempunyai status sebagai anak kandung.

\section{b. Konsep Dasar Tentang Wali Nikah dalam Islam}

secara etimologi wali mempunyai arti pelindung, penolong, atau penguasa. ${ }^{16}$ Menurut Syarifuddin Latif, memaknai kata wali secara universal, yang berasal dari bahasa Arab yaitu isim fa' il,masdar-nya adalah الولاية=wilāyah. Kata wilāyah secara etimologi berarti السلطة (kekuasaan) dan القارة (kemampuan). Karena itu wali berarti shahibul al-sultan (yang mempunyai kekuasaan dan kemampuan). Dalam literatul-literatul fiqih klasik dan kontemporer, kata al-wilayah digunakan sebagai wewenang seseorang untuk mengelola harta dan mengayomi seseorang yang belum cakap bertindak hukum. Dari kata inilah muncul istilah wali bagi anak yatim dan hartanya, dan orang yang belum cakap bertindak hukum. Sayyid Sabiq menegaskan terhadap defenisi wali yaitu suatu ketentuan hukum yang dapat

${ }^{15}$ Republik Indonesia, Undang-undang Nomor 1 Tahun 1974 Tentang Perkawinan dan Kompilasi Hukum Islam, (Bandung: CITRA UMBARA, t.th), h. 21.

${ }^{16}$ Tihami dan Sohari Sahrani, Fikih Munakahat (Kajian Fikih Nikah Lengkap), (Cet. II; Jakarta: PT Raja Grafindo Persada, 2010), h. 89. 
dipaksakan kepada orang lain sesuai dengan bidang hukumnya. ${ }^{17}$

Sedangkan menurut Dedi Supriyadi mengartikan perwalian yaitu "segala sesuatu yang berhubungan dengan wali." Dalam Kamus Besar Bahasa Indonesia kata wali mempunyai banyak makna, sebagaimana yang dikutip oleh Dedi Supriyadi antara lain:

1. Orang yang menurut hukum (agama, adat) diserahi kewajiban mengurus anak yatim serta hartanya, sebelum anak itu dewasa.

2. Pengasuh pengantin perempuan pada waktu menikah (yaitu yang melakukan janji nikah dengan pengantin laki-laki).

3. Orang saleh (suci), penyebar agama.

4. Kepala pemerintah dan sebagainya. ${ }^{18}$

Arti wali diatas tentu saja pemakaiannya dapat disesuaikan dengan konteks kalimat. Adapun yang dimaksud wali dalam pembahasan ini adalah wali dalam pernikahan yaitu yang sesuai dengan poin 2 .

Wali ditunjuk berdasarkan skala prioritas secara tertib dimulai dari orang yang paling berhak yaitu mereka yang paling akrab, lebih kuat hubungan darahnya.

Jumhur ulama fikih berpendapat bahwa urutan-urutan wali sebagai berikut:

1. Ayah;

2. Ayahnya ayah (kakek) terus keatas;

3. Saudara laki-laki seayah seibu;

4. Saudara laki-laki seayah saja;

5. Anak laki-laki saudara laki-laki seayah seibu;

6. Anak laki-laki saudara laki-laki seayah;

7. Anak laki-laki dari anak laki-laki saudara laki-laki seayah seibu;

8. Anak laki-laki dari anak laki-laki saudara laki-laki seayah;

${ }^{17}$ Sayyid Sabiq, Fiqih Sunnah, Terjemahan. Nor Hasanuddin, Dkk Jilid III (Cet. I; Jakarta: Pena Pundi Aksara, 2006), h. 11.

${ }^{18}$ Dedi Supriyadi, Fiqih Munakahat Perbandingan (DariTekstualitas Sampai Legislasi), (Cet. I; Bandung: CV PUSTAKA SETIA, 2011), h. 31. 
9. Anak laki-laki dari no.7;

10. Anak laki-laki no.8 dan seterusnya;

11. Saudara laki-laki ayah, seayah seibu;

12. Saudara laki-laki ayah, seayah saja;

13. Anak laki-laki no.11;

14. Anak laki-laki no.12 dan

15. Anak laki-laki no.13. dan seterusnya. ${ }^{19}$

Muhammad Jawad Mughniyah mengemukakan urutan wali menurut lima mazhab yaitu Hanafi mengatakan bahwa urutan pertama perwalian itu ditangan anak laki-laki wanita yang akan menikah itu, jika dia memang punya anak, sekalipun hasil zina. Kemudian berturut-turut: cucu laki-laki (dari pihak anak laki-laki), ayah, kakek dari pihak ayah, saudara kandung, saudara laki-laki seayah, anak saudara laki-laki sekandung, anak saudara laki-laki seayah, paman, anak paman, dan seterusnya.

Maliki mengatakan bahwa, wali itu adalah ayah, penerima wasiat dari ayah, anak laki-laki (sekalipun hasil zina) manakala wanita tersebut punya anak, lalu berturut-turut: saudara laki-laki, anak laki-laki dari saudara laki-laki, kakek, paman (saudara ayah), dan seterusnya, dan sesudah semuanya itu tidak ada, perwalian beralih ke tangan hakim. Sementara itu, urutan yang digunakan Syafi'i adalah ayah, kakek dari pihak ayah, saudara laki-laki sekandung, saudara laki-laki seayah, anak laki-laki dari saudara laki-laki, paman (saudara ayah), anak paman, dan seterusnya. Dan bila semuanya itu tidak ada, perwalian beralih ke tangan hakim.

Hambali memberikan urutan: ayah, penerima wasiat dari ayah, kemudian yang terdekat dan seterusnya, mengikuti urutan yang ada dalam waris, dan baru beralih ke tangan hakim. Sementara itu Imamiyah mengatakan bahwa perwalian itu hanya di tangan ayah dan kakek dari pihak ayah. Baik ayah maupun kakek mempunyai hak penuh dalam perwalian terhadap akad nikah bagi anak laki-laki dan perempuan kecil. Juga terhadap orang yang sudah baligh tapi gila atau idiot, bila mereka itu gila atau idiot sejak kecil. Akan tetapi bila ketika baligh mereka itu berakal sehat, lalu gila atau menjadi idiot, maka ayah dan kakek tidak punya hak perwalian atas kedua

${ }^{19}$ Tihami dan Sohari Sahrani, Fikih Munakahat, h. 91. 
jenis orang tersebut, tapi perwaliannya dipindahkan kepada hakim, sekalipun ayah dan kakeknya masih ada. Kalau sang ayah memilih seseorang (sebagai wali mereka), sedangkan kakeknya memilih orang lain, maka yang didahulukan adalah pilihan kakek. $^{20}$

Undang-undang Nomor 1 tahun 1974 tentang perkawinan, tidak jelas mengatur tentang wali nikah, tetapi disyaratkan harus ada izin dari orang tua bagi yang akan melangsungkan pernikahan dan apabila belum berumur 21 tahun disebutkan bahwa perkawinan harus didasarkan atas persetujuan kedua calon mempelai.

Mazhab Hanafiyah menyandarkan pada rasionalitas dalam membuat keputusan hukum tentang perwalian. Mazhab ini berpandangan bahwa status wali hanyalah syarat perkawinan, bukan rukun perkawinan. Mazhab Malikiyah berpandangan bahwa wali adalah syarat sahnya pernikahan. ${ }^{21}$ mazhab Syafi'iyah berpendapat sama terhadap status wali yaitu wali merupakan rukun yang harus dipenuhi dalam perkawinan.

Dasar hukum yang dipakai dalam keharusan adanya wali bagi seorang perempuan yang hendak menikah, berpedoman pada dalil-dalil diantaranya firman Allah SWT dalam QS. an-Nur (24): 32



Terjemahannya: 'Dan kawinkanlah orang-orang yang sendirian diantara kamu, dan orang-orang yang layak (berkawin) dari hamba-hamba sahayamu yang lelaki dan hamba-hamba sahayamu yang perempuan. jika mereka miskin

${ }^{20}$ Muhammad Jawad Mughniyah, Fiqih Lima Mazhab: Ja'fari, Hanafi, Maliki, Syafi'I, Hambali, (Cet. 14; Jakarta: PT Lentera Basritama, 2005), h. 347-348.

${ }^{21}$ Dedi Supriyadi, Fiqih Munakahat Perbandingan, h. 41. 
Allah akan memampukan mereka dengan kurnia-Nya. dan Allah Maha Luas (pemberian-Nya) lagi Maha mengetahui, ${ }^{22}$

Dan dalam Hadis riwayat dari Ibnu Majah, mengatakan bahwa Rasulullah SAW bersabda:

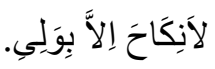
oleh wali ${ }^{23}$

Terjemahannya: 'tidak sah nikah kecuali (dinikahkan)

Menurut Sayyid Sabiq, syarat-syarat wali nikah yaitu harus merdeka, berakal sehat, dan dewasa atau baligh, baik dia seorang muslim maupun bukan. Sementara, macam-macam wali nikah terbagi atas dua kategori, yaitu wali nasab dan wali hakim. Wali nasab adalah orang-orang yang terdiri dari keluarga calon mempelai wanita, sedangkan wali hakim adalah orang uang diangkat oleh pemerintah untuk bertindak sebagai wali dalam suatu pernikahan.

\section{c. Analisis Hukum Islam Tentang Nasab Terhadap Ayahnya serta Penetapan Wali Nikahnya Bagi Anak Perempuan yang Lahir Kurang 6 Bulan}

Di Negara Indonesia kebanyakan menganut madzab Syafi'i, wali merupakan syarat sahnya pernikahan, jadi apabila pernikahan tanpa wali maka pernikahannya tidak sah. Kompilasi Hukum Islam (KHI) yang merupakan produk dari hukum Islam, juga memberikan penegasan bahwa wali dalam pernikahan merupakan rukun yang harus dipenuhi oleh calon mempelai wanita yang bertindak menikahkannya. Wanita yang menikah tanpa wali maka pernikahannya tidak sah.

Hal hubungan nasab anak dengan bapak tidak ditentukan oleh kehendak atau kerelaan manusia, namun ditentukan oleh perkawinan yang dengan nama Allah disucikan. Dalam hukum Islam para ulama berbeda pendapat dalam menetapkan hubungan nasab dengan ayahnya. Imam Syafi'i, imam Malik dan kawan-kawan ; apabila salah seorang laki-laki mengawini seorang perempuan yang belum pernah dikumpulinya atau sudah pernah, maka bila waktu kurang dari

22 Departemen Agama RI, Al-Qur'an dan Terjemahan, (Jakarta: Sygma, 2005), h. 354.

${ }^{23}$ Ibnu Majah, Sunan Ibnu Majah, (Juz I; t.tp: Dar Ihya al- Kutub alArabiyah, t.th), h. 605 . 
enam bulan dari akad perkawinannya perempuan tersebut melahirkan anak (bukan dari masa berkumpulnya), anak yang dilahirkannya itu tidak dapat dipertalikannya nasabnya kepada seorang laki-laki yang menyebabkan perempuan itu mengandung. Sedangkan imam Abu Hanifah memilih akad nikah sebagai dasar perhitungan enam bulan tersebut dimana konsekuensinya ketika anak tersebut lahir kurang dari enam bulan di hitung dari akad nikah maka anak itu tidak bisa dipertalikan nasab kepada ayahnya.

Penetapan wali nikahnya bagi anak perempuan yang lahir kurang 6 bulan tidak bisa diwalikan dengan bapaknya karena tidak ada hubungan nasab dengannya. Dalam hal penetapan wali nikah bagi anak perempuan yang lahir kurang dari 6 bulan dari perkawinan hamil terdapat dua rujukan. Yang pertama kalau kita merujuk pada pendapat ulama maka penetapan walinya harus menggunakan wali hakim, karena anak perempuan tersebut tidak memliki hubungan keperdataan (nasab) dengan bapaknya. Sedangkan yang kedua yaitu kalau merujuk pada hukum yang ada di Indonesia yaitu Undangundang No. 1 Tahun 1974 tentang perkawinan dan Kompilasi Hukum Islam (KHI), anak perempuan tersebut tetap sebagai anak yang sah walaupun anak perempuan tersebut lahir kurang dari 6 bulan. dan penetapan wali nikahnya tetap menggunakan wali nasab, karena tetap ada hubungan keperdataan (nasab) dengan bapaknya.

\section{F. Penutup}

Beberapa simpulan yang diberikan dari hasil pembahasan sebagai berikut:

1. Adapun hubungan nasab terhadap ayahnya bagi anak perempuan yang lahir kurang dari 6 bulan menurut hukum Islam adalah anak tersebut adalah anak tidak sah dan tidak bisa dinasabkan dengan ayah biologisnya karena tenggang waktu kelahiran dengan pelaksanaan perkawinan sedikitnya 6 (enam) bulan sejak perkawinan dilaksanakan. Hal ini terjadi ijma para pakar hukum Islam sebagai masa terpendek dari suatu kehamilan, dan juga seluruh madzab fiqih baik Sunni maupun Syi'ah sepakat bahwa batas minimal kehamilan adalah 6 
(enam) bulan sebab sekurang-kurangnya wanita hamil adalah selama enam bulan. dan apabila anak tersebut dianggap sebagi anak yang sah, maka nasab anak perempuan tersebut tetap pada ayah biologisnya.

2. Adapun penetapan wali nikahnya bagi anak perempuan yang lahir kurang dari 6 bulan menurut hukum Islam, apabila anak perempuan tersebut adalah anak tidak sah maka penetapan walinya adalah harus menggunakan wali hakim untuk menikahkannya. Dan jikalau anak perempuan tersebut dianggap sebagai anak yang sah, walaupun lahir kurang dari 6 bulan, maka penetapan walinya tetap menggunakan wali nasab. 


\section{G. Daftar Pustaka}

Dahlan, Abdul Aziz dkk. Ensiklopedi Islam. Cet. III; jilid. IV; Jakarta: PT Ichtiar Baru Van Hoeve, 1994.

Departemen Agama RI. Al-Qur'an dan Terjemahan. Jakarta: Sygma, 2005.

Kompilasi Hukum Islam. Bandung: CITRA UMBARA, t.th.

Manan, Abdul. Aneka Masalah Hukum Perdata Islam di Indonesia. Cet. I; Jakarta: Kencana, 2006.

Majah, Ibnu. Sunan Ibnu Majah. Juz I; t.tp: Dar Ihya al- Kutub al- Arabiyah, t.th.

al-Mugniyah, Muhammad Jawad. al-Fiqh alaa al-Mazahib alKhamsah. Cet. VI; t.tp: t.p., 1402 H/1982 M.

. Fiqih Lima Mazhab: Ja'fari, Hanafi, Maliki, Syafi'I, Hambali. Cet. 14; Jakarta: PT Lentera Basritama, 2005.

Munawir, Ahmad Warson. Kamus al-Munawir Arab-Indonesia. Ed. II. Surabaya: Pustaka Progresif, 1997.

Poerwadarminta, WJS. Kamus Besar Bahasa Indonesia. Jakarta: Balai Pustaka, 2008.

Republik Indonesia, Undang-undang Nomor 1 Tahun 1974 Tentang Perkawinan dan

Sabiq, Sayyid. Fiqih Sunnah, Terjemahan. Nor Hasanuddin, Dkk, Jilid III. Cet. I ; Jakarta: Pena Pundi Aksara, 2006.

Supriyadi, Dedi. Fiqih Munakahat Perbandingan (DariTekstualitas Sampai Legislasi). Cet. I; Bandung: CV PUSTAKA SETIA, 2011. 
Tihami dan Sohari Sahrani. Fikih Munakahat (Kajian Fikih Nikah Lengkap). Cet. II; Jakarta: PT Raja Grafindo Persada, 2010.

al- Zuhailiy, Wahbah. Al-Fiqh al- Islamiy wa Adillatuhu. Jilid I. Beirut: Dar al-Fikr, 1984. 